本セッションは一般セッションでもあり，テーマにまと まりはなかったものの, 常に 35〜45 人の参加者を数え,
最後の最後まで活発な質疑応答が行われたことは特筆に值 しょう。

\title{
一般セッション
}

\section{超臨界流体利用・発泡成形 1（F-101～F-105）}

超臨界流体利用・発泡成形は一日目と二日目の午後に セッションが開かれ，14件の発表が行われた. 今回は従 来の熱可塑性の発泡成形以外にも, 熱硬化性樹脂や架橋構 造を持つ樹脂の発泡や微細孔の形成に注目が集まった。こ こでは，F-101〜 F-105 の報告をまとめる.

ポリ乳酸のバッチ発泡では，ポリ乳酸構造中の $\mathrm{C}=\mathrm{O}$ 基 が $\mathrm{CO}_{2}$ の局在化に寄与し気泡生成のサイトになりうるこ とが示唆された $(\mathrm{F}-101)$.気泡の中に金属球を入れた鈴 構造体の防音特性に関する研究では, 音響試験の結果ある 一定の周波数では防音効果があることが示された（F-102）.

\footnotetext{
* Taki, Kentaro

京都大学 大学院工学研究科化学工学専攻 京都市西京区京都大学桂 （ $7615-8510 ）$ 2008.11.5 受理
}

ポリスチレン発泡体の気泡径とその光反射性についての研 究では, Mie 散乱と Debye 散乱が寄与しており, 特に, 正面からの反射は Mie 散乱の影響が大きいことが理論と 実験から明らかになった。発泡体を反射板とする場合，気 泡が小さすぎても反射率の構造は望めず，樹脂の屈折率に 関係した最適な気泡径があることが明らかになった（F103)。超臨界 $\mathrm{CO}_{2}$ 下での延伸では，延伸装置に歪みゲー ジが取り付けられ，応力一ひずみ曲線が HDPE，LDPE， $\mathrm{PC}$ で測定し, 一様に発生する応力は減少し破断ひずみは 増加することという可塑化効果が明らかになった（F-104）。 エポキシ樹脂のレオロジー特性と発泡体の関係では，樹脂 の伸長粘度が気泡の合一と最終構造に関与していることが 明らかになった $(\mathrm{F}-105)$.

\section{一般セッション}

\section{超臨界流体利用・発泡成形 $2 （ \mathrm{C}-209$ ～C-217）}

木 原 伸 一*

本セッションでは，超臨界流体を利用した発泡体成形の 基礎から応用まで幅広く議論された. 低分子とポリマーと の物理化学的な関係と力学物性の関係の把握が基本にあり, プロセスでどのようにそれを引き出すかの視点と静的な物 性と動的な物性との対比が重要であろう。今回の発表では, 超臨界流体をポリマーに溶解させ発泡体形成過程の力学的 な変化を評価する内容が多く，延伸や架橋硬化反応を利用 した発泡が新しく感じられた。二日目の会場の聴講者はお およそ20３0 名程度であったが，参加メーンバーが常連 となりつつあり，質問者が限られている印象を受けた．関 連分野とうまくコラボレーションできる場になればより活 発な意見が出て良いように思えた。 以下に，C-209〜C-217 で発表された概要を筆者の理解でまとめる。

(1)溶解特性を中心に議論された研究：VOC 削減に $\mathrm{CO}_{2}$ を利用するために, 多種多様な有機溶媒と超臨界 $\mathrm{CO}_{2}$ と の関係を溶解度パラメータ SP 值により整理し, ポリマー 溶液が貧溶媒化する相挙動について報告された（C-209）。 (2)延伸を利用した発泡に関する研究：ポリカーボネート （PC）を延伸する際，ネッキング時の配向結晶化を誘起す ることにより，ナノ発泡体が形成されることが報告された。

\footnotetext{
* Kihara, Shin-ichi

広島大学 大学院工学研究科物質化学システム専攻

東広島市鏡山 1-4-1（７339-8527）

2008.11. 5 受理
}

PC には恐らく微結晶があり, それが力学的な基点として 延伸プロセスで配向することで，ナノスケール構造を形成 させる点で興味深いものであった $(\mathrm{C}-210)$. (3)架橋硬化 反応を利用した発泡成形に関する研究：エポキシ樹脂をモ ノマーから架橋形成とともに発泡させ，線形粘弾性による 弾性評価から気泡径に関する情報を得る方法論について報 告された $(\mathrm{C}-211)$. 一方で，安定した断熱用発泡構造体 を製造するために，UV 架橋させて断熱用ガスの拡散性の 低下を狙った研究も報告された $(\mathrm{C}-212)$. UV 硬化モノマー $/ \mathrm{PS} / \mathrm{CO}_{2}$ 系に UV 照射し，架橋反応熱を利用して，架橋 形成とともに発泡させる。UV 照射強度の強弱により厚み 方向に気泡分布を作ることができ，ガスの拡散係数は 10 分の 1 程度まで小さくできることが示された，他方で，ス ポーツ靴を対象に，EVAの架橋発泡成形プロセスに対し， 特定周波数の線形粘弾性を測定し，実際のプロセスでの発 泡外観と内部の SEM 画像との対比から最適な製造条件を 探索した結果が報告された $(\mathrm{C}-217)$. Puls NMRで架橋 密度を測定し, 架橋密度を基準としてレオロジー特性を 使ってプロセスマップが作成され点は興味深い. (5)発泡プ ロセスに関する研究：二重円筒ノズルを用い連続的に PVA ハニカム構造体を作製する方法について報告された (C-213).二重円筒の中心に $\mathrm{CO}_{2}$ などのガス，外層に PVA 溶液を配置して押出し，フロースを堆積させて気泡膜を作 る. 界面活性剤を入れると表面電気二重層のため気泡間膜 